\title{
O potrebe talentových skúšok nielen na umeleckých študij- ných odboroch
}

\section{Valerián Franc}

Envigogika 11 (2) - Inspirace/ Inspiration

Publikováno/Published dne 28. 10. 2016

DOI: $\underline{10.14712 / 18023061.535}$

\begin{abstract}
Abstrakt
Článok hladá odpovede na zložité otázky profesionálnych predpokladov na vykonávanie povolania učitel'a prírodných vied, zvlášt́ biológie. Odcudzenie človeka prírode, ktoré sa i v 21. storočí neustále prehlbuje, vytvára predpoklady pre nežiaduce a úplne bezdôvodné fóbie, ktoré sa týkajú "tradičných" živočíchov, ako sú hady, myši, netopiere a samozrejme pavúky. Živočíchov, z ktorých majú strach nielen dámy, ale i páni, zdá sa, stále pribúda objektom strachu alebo odporu už môžu byté i také živočíchy, ako jašterica, žaba, dážd'ovka, húsenica, a dokonca i pes a mačka (Katrenčíková, 2016). Hlavnou príčinou zoofóbií je ale nevedomost́: súčasná verbálno-teoretická koncepcia vyučovania biológie (aspoň na Slovensku) sa odráža vo vel'mi slabej úrovni poznania živých organizmov u majoritnej časti nastupujúcej generácie. Žial', stáva sa už dost́ často, že študentke, ale i študentovi, ktorí nastúpili na učitel'ské štúdium biológie, sa bridí žaba, slimák, dážd’ovka, o fóbických stavoch z hadov a pavúkov ani nehovoriac. Je vel'mi diskutabilné, ako môže takáto osoba o niekolko rokov vykonávat' povolanie učitela biológie. $Z$ týchto dôvodov treba seriózne uvažovat' o potrebe zaradenia talentových skúšok pre budúcich učitel'ov biológie; týmto by sa "odfiltrovali" osoby, ktoré sa pre neprekonatel'ný odpor k niektorým živočíchom za učitel'ov biológie jednoducho nehodia.
\end{abstract}

\section{KI'účové slová}

Talentové skúšky, vyučovanie biológie, zoofóbie, profesionálne předpoklady

\begin{abstract}
This text seeks to answer the difficult question of professional qualifications required to practice as a teacher of natural sciences, biology in particular. The alienation of humanity from nature which increases as the 21st century continues creates the conditions for undesirable and unfounded phobias related to "traditional" animals such as snakes, mice, bats and spiders, of course. Fears of these animals are steadily increasing. The object of fear or resistance includes animals such as lizards, frogs, earthworms, snails, caterpillars, even cats and dogs. The main reason for zoophobia is insufficient knowledge: the current verbal-theoretical concept of teaching biology (at least in Slovakia) is reflected in a very limited
\end{abstract}


knowledge of living organisms among the majority of the current generation of students. It is unfortunately common that students embarking on their studies to train as biology teachers fear frogs, snails, earthworms, not to mention phobias of snakes and spiders. It is questionable whether it is appropriate for such a person to go on to teach biology. We should therefore seriously consider the necessity of aptitude tests for future biology teachers; this would help "filter out" those who, due to an insurmountable aversion to some of animals are not suitable to practice as biology teachers.

\section{Key words}

aptitude tests, teaching of biology, zoophobia, professional suppositions 


\section{Preambula}

Krásny rozkvitnutý májový deň, známa lesostepná lokalita pri Zvolene (NPR Boky), slniečko a spev vtákov - pohoda, akú t́ažko opísat' slovami. Každoročné terénne cvičenia zo zoológie pre študentov biológie na našej fakulte opät vyšli. Niečo tu však (opät́) nehralo...

Sympatická tvár mladej slečny skrivená nepeknou grimasou, zrýchlený dych, nekontrolovaný náznak akéhosi výkriku a pohl'ad hrôzy v očiach - možno väčšiu hrôzu mala v očiach iba Ripleyová pri pohl'ade na votrelca v svetoznámom horore. Čo spôsobilo tieto negatívne emócie a sprievodné fyziologické stavy u našej študentky? Elegantná, pôvabná a úplne neškodná užovka hladká (Coronella austriaca). Najhoršie na tom je, že tieto fóbické stavy sa týkali budúcej učitelky biológie!

\section{Úvod}

Rovnost́ medzi l'ud'mi je často diskutovaná a dost' kontroverzná téma. Jedno je isté: aspoň pred zákonom by mali byt' ludia rovní, i ked’ v praxi to niekedy vyzerá tak, že niektorí sú „rovnejší". Pod'me sa však bavit' o inej rovnosti - o rovnosti možností a predpokladov profesionálneho uplatnenia. Je iluzórne tvrdit', i ked' len čisto teoreticky, že každý by mohol študovat' na akejkol'vek škole, presnejšia akýkol'vek študijný odbor. Niektoré študijné odbory a povolania sú tak špecifické, ža vyžadujú istý typ osobnosti. Skôr si myslím, že pre niektoré oblasti ludskej aktivity sa skôr hodí slovo poslanie, než povolanie - pre profesiu učitela, ale i lekára to platí asi na prvom mieste. Neviem si predstavit', ako by mohol povolanie lekára, zvlášt́ chirurga, vykonávat́ človek, ktorému sa hnusí krv. Rovnako je nepravdepodobné, či skôr nemyslitel'né, aby náročné povolanie pilota zverili človeku, čo má panický strach z výšky. Plavčíka, samozrejme, nemôže robit' človek, čo má fóbiu z vody. Ked’by sme z tohto mali sformulovat́ niečo ako filozofický záver, treba povedat', že l'udia sú (resp. mali by byt') rovní pred zákonom, rovnako ako sú si rovní, ked' vstúpia do volebnej miestnosti. Tým sa všetka rovnost' končí, pretože l'udia sú variabilní: jeden má osobnostné (fyzické i psychické) predpoklady pre šport, druhý pre umenie, tretí pre vedu, štvrtý pre riadiace procesy...

Niektoré študijné odbory a povolania sú tak špecifické, že pri výbere záujemcov sú nevyhnutné tzv. talentové skúšky. Väčšinou ide o umelecké alebo športové odbory. Malo by význam, aby hru na klavíri, alebo inom hudobnom nástroji šiel študovat́ mládenec, ktorý, ako sa ironicky hovorí, má "hudobný hluch"? Štúdium hudby by bolo u tohto človeka kontraproduktívne - zrejme nie je predurčený na to, aby bol hudobníkom; môže však byt́ výborný lekár alebo vedec. Rovnako u mladých ludí, ktorí chcú študovat́ telovýchovné a športové aktivity, sa vyžadujú isté predpoklady, preto sú súčastó prijímacieho konania talentové skúšky. Nemalo by význam, aby atletiku alebo iný šport šiel študovat' mládenec alebo slečna napr. s chorými kíbami alebo iným vážnym hendikepom. Konečne sa dostávame k vysloveniu kardinálnych otázok: Je učitel'ské povolanie (= poslanie) nejaké menejcenné? Môže za učitela (presnejšie učitel'a biológie) študovat' každý? Odpovede na tieto otázky budeme hl'adat́ v nasledujúcom odseku.

\section{Ako hl'adat' riešenie?}

Spoločenská prestíž a "šmrnc" učitel'ského povolania za posledných cca 30 rokov vel'mi upadli, čo je zretel'né najmä na Slovensku, ale čiastočne i v iných krajinách tzv. Ostbloku. Prejavuje sa to okrem iného aj na platoch učitel'ov, ale hlavný problém nie je iba v peniazoch. Vrátime sa k dileme, či učitel'om môže byt́ každý. Ako dlhoročný pedagóg som presvedčený o tom, že zd’aleka nie každý môže byt' učitel'om, presnejšie, zd'aleka nie každý môže byt́ 
dobrým učitel'om. Povolanie učitela (nielen lekára, pilota a športového trénera) vyžaduje isté osobnostné predpoklady, dalo by sa povedat' „talent". Uvediem markantné príklady.

$\mathrm{Na}$ štátniciach $v$ minulom akademickom roku študentka začína s prezentáciou svojej diplomovej práce. Hovorí tichúčko, s nevýraznou výslovnost́ou a monotónou intonáciou. Tiché nesmelé introvertné dievča, takmer až na hranici s autizmom. Neviem si predstavit', ako by sa táto krehká a plachá žienka postavila pred triedu 14-ročných junákov v puberte a začala vyučovaciu hodinu. Je jasné, že $z$ hladiska typológie osobnosti je táto osoba vyložene nevhodná pre učitel'skú profesiu. Ale možno že by z nej bola vynikajúca zdravotná sestra...

Učitelia dobre vedia, že každý vyučovací predmet je špecifický. Iné pedagogické prístupy a didaktické metódy používa učitel' matematiky, iné učitel' biológie, iné učitel' angličtiny. A ešte jedna dôležitá poznámka: Nie každý učitel' sa hodí na vyučovanie každého predmetu. Niekto má matematické a logické myslenie, a môže z neho vyrást́ výborný učitel' matematiky, s biológiou by ale mohol mat́ problémy, lebo nemá napr. fotografickú pamät. Spomínaná "fotografická" (alebo obrázková) pamät je obrovskou výhodou biológa, ktorý si l'ahko zapamätá tisíce druhov rastlín a živočíchov, pretože si to "ukladá" ako súbor obrázkov, nie ako textový súbor. Študentom už dlhé roky zdôrazňujem, že kto by sa chcel naučit́ biológiu naspamät' (ako báseň), podstupuje utrpenie so slabučkým výsledkom, lebo biológia sa naspamät naučit' nedá.

Existujú isté všeobecné osobnostné, charakterové a komunikačné predpoklady pre učitel'ské povolanie: schopnost́ komunikácie, správna výslovnost' a intonácia hlasu, empatia, spravodlivost', dochvil'nost', presnost'... a samozrejme, dobrý učitel' by mal mat úhl'adný rukopis a mal by vediet' kreslit'. Ďalšie predpoklady sa už odvíjajú od konkrétneho predmetu: Niekomu "sadne" matematika, iný matematiku berie ako nutné zlo, ale môže byt́ výborným učitel'om jazykov. Tu je potrebné vyslovit' jednu zásadnú tézu: Dobrý učitel' musí mat' pozitívny a nepredstieraný vztáah k predmetu, ktorý učí. Musí byt́ entuziasta, ktorý motivuje a "hecuje" študentov ku štúdiu svojho predmetu. Ked' som sa našich študentov pýtal, či počas gymnaziálneho štúdia biológie boli na exkurzii v prírode, prevažovali odpovede jeden, vzácne dvakrát, asi tretina však konštatovala, že ani raz... Na nepekný, ale demonštratívny zážitok si spomenul jeden náš študent. Boli na exkurzii s učitelkou koncom 2. ročníka v Kremnických vrchoch. Študent niekde v lese pod kameňom našiel ropuchu. Reakcia učitelky: „Fuj, pustite to." Áno, fuj, taká učitelka...

Niektorí študenti mi naznačili, že ich (väčšinou) učitelky sa boja íst' so žiakmi na exkurziu do prírody, pretože - preboha, čo ked' uvidíme hada, čo ked' niekoho bodne osa, čo ked' žiaci donesú kliešte!... Aký prínos - gnozeologický (informatívny), ale najmä vzt́ahový (formatívny) má pôsobenie takéhoto "učitel'a" biológie pre prax? Priznajme si konečne, že nepatrný, ak nie celkom nulový. A propos: fenomén strachu. Strach je prirodzeným stavom psychiky, resp. nervovej sústavy nielen u človeka, ale i u iných živočíchov; stimuluje produkciu adrenalínu, a živočích (vrátane človeka) sa snaží čím skôr dostat' z dosahu nebezpečenstva. Pochopitel'ný a opodstatnený je strach (alebo skôr rešpekt) v prípade medved’a, ale i diviaka, jedovatého hada, škorpióna, zo sršnieho hniezda v dutom strome; pretože za istých okolností môžu spôsobit' vel'mi nepríjemný zážitok, prípadne i ohrozit život človeka. Fóbický strach je však väčšinou charakteristický iracionálnostou, nedá sa vysvetlit' logickými argumentami. Hlavnou príčinou zoofóbií je nedostatok informácií o živočíchoch, resp. prekrútené a skreslené "polopravdy" o nich. Do tejto kategórie patrí utkvelá predstava časti verejnosti o slizkosti hadov - pritom každý, čo držal hada, vie, že je na dotyk príjemný a jemný, ako kvalitná kožená kabelka. Hoci to ostro kontrastuje s dnešnou informatickou spoločnostou, niekedy mám pocit, že úroveň (ne)vedomostí časti populácie o živočíchoch je na úrovni hlbokého stredoveku (Franc, 2014). 
Smutné, rozpačité, ale poučné zážitky mám z cvičení, kde pozorujeme živočíchy pod binokulárnou lupou. Študenti až na vysokej škole zist'ujú, aké sú živočíchy nádherné. Mojej pozornosti neušlo, ako uprene kukali študenti do binokulárov na blyskavky (Chrysididae) a krasone (Buprestidae) s nádhernou kovovou metalízou, ako i na bzdochy sietnačky (Tingidae) s bizarnou „čipkovanou" skulptúrou celého tela. Boli zjavne prekvapení takou krásou. Chyba! Tú krásu im mali ukázat' a sprostredkovat́ už predo mnou učitelia na gymnáziách. Žial', neurobili tak takmer ani v jednom prípade.

Diagnóza je chyba systému. Učitelia sú slabo motivovaní (finančne ale i morálne nízkou spoločenskou prestížou), učebnice sú slabé, koncepcia vyučovania verbálno-teoretická, syntetická, žiaci sa s prírodninami (rastlinami a živočíchmi, pričom existuje ešte obrovská ríša húb!) takmer vôbec nestretnú, vztahohó väzby k prírode sa rozvíjajú slabučko. Biológia je král'ovskou vedou, ako tvrdil svojho času Ch. Darwin, pretože skúma „zázračný" fenomén života. Ved'i my sme živé tvory, a preto by nám biológia mala byt́ najbližšou vedou.

Žial', nie všetci učitelia biológie sú entuziasti, pre ktorých je biológia «srdcovou záležitost́ou». Domnievam sa, že z mladého človeka, ktorý nemá pozitívny vzt́ah k prírode, resp. má averziu, či dokonca panický strach čo i len z niektorých živočíchov, dobrý a oduševnený učitel' biológie zrejme nikdy nebude. Som si vedomý dôležitosti biológie na prahu 3. tisícročia, v dobe prehlbujúcich sa globálnych environmentálnych problémov a stále narastajúcemu úbytku biodiverzity. Preto by sme mali výberu a príprave budúcich učitel'ov biológie venovat́ mimoriadnu pozornost'. Som presvedčený o tom, že budúci učitelia biológie by mali prejst' niečím ako «talentové skúšky», ktoré by odhalili, či majú predpoklady stat́ sa dobrými, kreatívnymi a celou svojou osobnost́ou angažovanými učitel'mi biológie, bez nežiaducich informačných šumov, predsudkov a zoofóbií. Je kontraproduktívne a skoro až trápne, ak sa učitel'ka biológie striasa pri pohl'ade na celkom neškodného pavúka, a na ropuchu povie fuj. Takíto učitelia (dúfam, že ich nie je vel'a) nemajú za katedrou čo hladat', mali si vybrat́ iné, „nebiologické" zamestnanie. Týmto článkom by som chcel naštartovat' diskusiu o tomto prehliadanom probléme a súčasnej neutešenej situácii medzi zainteresovanými aspoň v Slovenskej a Českej republike.

\section{Referencie}

- Franc, V. (2014). O „stredovekej" zoológii v 21. storočí. Bulletin Slovenskej zoologickej spoločnosti (Zvolen) 2/2014: 1-5.

- Katrenčíková, D. (2016). Zoofóbie - nežiaduci, no rozšírený fenomén v živote moderného človeka 21. storočia. [Bakalárska práca.] Fakulta prírodných vied UMB, Banská Bystrica, 43 pp.

Doc. PaedDr. Valerián Franc, CSc. Katedra biológie a ekológie, Fakulta prírodných vied UMB, Tajovského 40, 97401 Banská Bystrica 